\title{
Response to Jewell, Evan. (Re)moving the Masses: Colonisation as Domestic Displacement in the Roman Republic. Humanities 2019, 8, 66
}

\section{Peter Gatrell}

Department of History, School of Arts, Languages and Cultures, University of Manchester, Manchester M13 9PL, UK; peter.gatrell@manchester.ac.uk

Received: 15 October 2019; Accepted: 16 October 2019; Published: 24 October 2019

\begin{abstract}
This response engages with Evan Jewell's article on 'Colonisation as Domestic Displacement in the Roman Republic'. It supports his argument about the relationship between the conduct of politics in the ancient world and the use of aquatic metaphors to target specific groups for displacement, adding that similar relationships unfolded in more recent times. His emphasis on 'domestic displacement' also resonates with twentieth-century projects that displaced people in large numbers in pursuit of what has come to be called 'development'.
\end{abstract}

Keywords: refugees; metaphors; Roman colonisation; development-induced displacement

I read with great interest Evan Jewell's sweeping and informative article about metaphors of displacement and how metaphors, like human beings, travel across time and space. I also applaud his invitation to relate metaphor to the changing contours of politics and how these contours informed the use of metaphor. He does this by invoking classic statements by Cicero and others who supported the displacement of 'surplus' non-elite populations from ancient Rome in order to help colonise other parts of the Roman Empire (Jewell 2019, p. 1). I hope Jewell's article gains a wide readership beyond a specialist audience interested in the social and political history of ancient Rome.

Two metaphors stand out in particular: the notion of 'waste' and the concept of 'drainage'. But these metaphors did not float freely: as Jewell argues, they were linked to practice, and specifically associated directly with Julius Caesar's colonisation programmes.

Jewell ends with some remarks about contemporary attempts to marshal classical ideas of asylum, suggesting instead that we should pay closer attention to the less than 'humanitarian' origins of Rome, which has sometimes been interpreted as a city that offered hospitality towards exiles including outlaws and convicts.

Rather than separate metaphor and practice, I shall likewise connect my remarks about metaphor to the relationship between rhetoric and practice in modern statecraft.

Jewell is right to say that the circulation of aquatic metaphors in current debates is not confined to those who wish, as they would put it, to 'stem the tide of migration'. Those who support the rights of migrants and refugees are also apt to couch their advocacy in aquatic terms. In addition to the example of Ai WeiWei, the work of Jason deCaires Taylor is also couched in such terms. Specifically, his 2016 installation, Museo Atlántico, located on the sea bed off Lanzarote, was a powerful meditation on the risks faced by migrants. But it was also troubling in so far as it largely sidestepped the contextualisation of displacement. ${ }^{1}$ Other installations repeated the theme of being submerged. As his website explains:

1 According to his website, 'The works create a strong visual dialogue between art and nature. They question the commodification and delineation of the world's natural resources and raise the alarm of the current threats facing the world's 
The Raft of Lampedusa carries 13 refugees towards an unknown future. It draws its inspiration from Théodore Géricault's Raft of the Medusa which represents the vain hope of shipwrecked sailors. Despite being able to see the rescue vessel on the horizon, they are abandoned to their fate-much as refugees are today. Even as raft after raft of refugees is lost beneath the waves of the Mediterranean, as the bodies of children wash up on European shores, Fortress Europe has withdrawn rescue operations, built barriers, turned away. Taylor cast refugee Abdel Kader as the figurehead of The Raft of Lampedusa. Kader comes from Laayoune, the largest city in Western Sahara, and made his own perilous journey by boat to Lanzarote 16 years ago when he was only 13 years old. The Rubicon features 35 people walking towards an underwater wall, unaware that they are heading to a point of no return. They look down or look at their phones, in an almost dreamlike state. This is a recurrent theme in Taylor's work-that we are sleepwalking towards catastrophe, unable to take stock of our own impact on the natural world and therefore our own survival.

Nevertheless, the aesthetic quality of the installation is what sticks in the mind. The other figures are not referred to by name. Nor do we learn of Kader's subsequent fate.

The work of artists such as WeiWei and Taylor made me think of the remarks of anthropologist Liisa Malkki, who highlighted the widespread tendency of aid organisations and others to focus on the pure suffering of victims who lacked a name and whose motives remained hidden from view through this kind of de-politicised discourse (Malkki 1996).

Not everything is de-politicised, of course. Opponents of mass migration often argue that the risks faced by migrants who take to flimsy boats would be greatly reduced if they were deterred by firmer measures on the part of destination countries.

Like Jewell, I have been struck by the widespread deployment of aquatic metaphors to describe contemporary mass migration. Opponents of migration might express sympathy for those who drown at sea, but they are more preoccupied with the prospect that 'native shores' are at risk of being inundated. Henry Berénger, the chief French delegate to the Evian Conference in 1938 spoke of France having 'reached, if not already passed, an extreme point of saturation as regards the admission of refugees' (quoted in Ahonen 2018, p. 144).

Historically, other metaphors circulated too. During the First World War, observers of the sudden displacement of civilians from the western borderlands of the Russian Empire to the interior spoke not only of flood and being 'deluged', but of 'earthquake', 'avalanche' and 'volcanic lava'. The metaphor of 'swarm' also circulated, to characterise the crisis as one in which Russia faced imminent disaster from a plague of locusts. It was sometimes easy to forget that one was talking about human beings: admittedly not, in this context, citizens with rights, but nonetheless people who might expect a degree of protection from the emperor to whom they were subject (Gatrell 1999, p. 200). These metaphors coexisted with other invocations of real or potential disaster-think, for example, of the way in which Hutu extremists in 1959 described the Tutsi population of Rwanda as 'cockroaches', or the Nazi discourse of Jews as 'unhealthy elements', 'fungus' and 'vermin'. But it is the aquatic metaphor that, so to speak, takes pride of place (Bauman 1989, pp. 66-72; Gatrell 2013, p. 232). In one atrocious instance, British Conservative MP, Bill Cash, speaking in the House of Commons in September 2015, described Syrian refugees as a 'tsunami' that threatened to 'swamp Europe'.

However, Jewell is less concerned with the implications of aquatic and other metaphors as a means of characterising the consequences of mass displacement than he is with their deployment as

oceans. The installations highlight the social and political divisions within today's society.' https://www.underwatersculpture. com/?doing_wp_cron=1569435902.8521459102630615234375).

2 https://www.independent.co.uk/news/uk/politics/tory-mp-describes-syrian-refugees-as-a-tsunami-that-could-swampeurope-10503565.html. Inexcusably, and at exactly the same time, Amin Awad, Director of the Middle East and North Africa Bureau of the Office of the UN High Commissioner for Refugees, used the terms 'avalanche' and 'tsunami' to dramatise the 'crisis'. https://news.un.org/en/story/2015/09/509742-syria-un-cites-utter-desperation-behind-tsunami-refugees-europe. 
part of the armoury of inflicting harm, in other words how they serve to target individuals or groups. In Republican Rome, Cicero and others deployed the dehumanising rhetoric of 'waste' (as in waste water) and 'dregs' to justify driving people from their homes and to pave the way for a concerted drive of colonisation across the Mediterranean. In this reading of the sources, Jewell reframes displacement as the result of intense pressure applied by Roman elites on the plebeian population (who lived in close proximity) in order to sustain and enhance their hegemony. Jewell's interpretation thus also opens up space for discussing the politics of 'domestic displacement', namely the elite's attempt to nip in the bud any political assertiveness on the part of non-elite groups, including freedmen.

Julius Caesar intended colonisation as a form of poor relief that would provide the urban poor with cultivable land in the colonies and help buy their support or at least acquiescence. Thus the colonisation drive was not simply undertaken in order to reward military veterans but also as a strategy to negate potential plebeian protest, particularly at times of dearth in Rome and its environs. At times, such as during the reduction in the government grain dole, Romans had little choice but to migrate elsewhere. So 'push' factors certainly came prominently into play.

At the same time, Jewell's discussion of the prospective settlement of Romans in the plague-ravaged Volscian city of Velitrae indicates that their acquiescence could not be counted on. Despite facing penalties for refusing the offer of resettlement, some Romans objected to the proposition. Those who took up the offer subsequently abandoned the colonies when conditions worsened. Although some may have been more or less willing recruits for resettlement, they soon became aware that its opportunities had been greatly exaggerated.

This kind of 'domestic displacement' reminded me of attempts by the Indian government after 1947 to settle Partition-era refugees on swamp-infested land, and their resistance to these attempts. To be sure, Indian planners were faced with an acute refugee crisis, and in the ensuing years. Whereas elite refugees were able to create self-settled refugee 'colonies', non-elite refugees were organised into dedicated camps. A particular source of pride to the new Indian government was the Dandakaranya Development Authority in Orissa, which was conceived in 1958 as a means to resettle refugees from East Pakistan in 'a sort of backwater that the tides of modern civilisation passed by'. With the help of overseas agencies such as Church World Service, trees were felled and new villages were established, having been 'planned to the last detail'. Lutheran World Relief described how its 'Project Daya' ('mercy' in Bengali) would contribute to the 'rehabilitation of these uprooted, plundered, profaned and disinherited people-re-establishing them in responsible social positions'. Dandakaranya, it added, was expected to provide unreclaimed land 'inhabited largely by small groups of aborigines'. It was, in essence, envisaged as a project to modernise Indian society and to cement the commitment of refugees to the new state (Gatrell 2013, pp. 162-63).

Dandakaranya was, however, only a qualified success from the government's point of view. Refugees-prompted by the Communist Party's tactics of undermining the ruling Congress Party-rejected it in favour of the Sundarbans, the reclaimed mangrove swamps of the Bay of Bengal whose environment was more familiar to them, or opted for the Andaman Islands (Ghosh 2000). Here, as emerges to some extent in Jewell's account, displaced persons were able to exercise a degree of agency.

What took place in ancient Rome is akin to the politics of what is today called development-induced displacement. Jewell refers to contemporary Brazil, where the new government of Bolsonaro energetically supports the interests of urban elites at the expense of the urban (and racialised) poor. Many of these issues have of course been central to broader debates in anthropology and human geography, as in the classic work of Colson $(1971,2003)$ and more recent contributions (Bennett and McDowell 2012). The Dandara piece published in this collection is a further reflection on such issues from the perspective of Brazil's Landless Peasant Movement (Ribeiro et al. 2017, in this volume). What emerges is the contempt that developers and planners have shown towards those targeted for dispossession and displacement, and the social and psychological consequences inflicted upon them. Without going overboard (to adapt another aquatic metaphor), it is worth pointing to 
the connection - metaphorical and material—between the doctrine of engineering development and designing 'improvements' to society that rely upon the excision of unwanted 'elements' (Weiner 2003).

To be sure, displacement cannot be written in a single register. Reflecting on the abrupt dislocation that followed the construction of the Tarbela Dam that began in 1976, Olivia Bennett and Christopher McDowell found that their informants lamented that 'no-one knows us' in the new townships located in Punjab and Sindh. At the same time, they detected some evidence that displacement allowed villagers to free themselves from exploitation by Pathan landlords. Furthermore, displaced people were ready to acknowledge that the development project provided them with electricity and other utilities. Nevertheless, the overwhelming sense from this personal testimony was one of loss. In discussing the lives of people directly affected by the ambitious and costly Molika-liko Dam Project in Lesotho designed to ease the supply of water to South Africa, one informant summed up her experiences in the words, 'we are nothing'; another asked, 'what else can we do?'. In a familiar refrain, speakers described their profound unease at having to relocate to unfamiliar surroundings where money spoke louder than customary practice and networks of mutual obligation. Poignantly, they feared that they had 'betrayed' their ancestors as well as the next generation (Bennett and McDowell 2012, pp. 37-65, 151-57).

Jewell ends with a series of reflections on the scope for further research, including the need to pay some attention to the economics of displacement. I agree, although there is quite a substantial a body of existing work on this topic (Rao 1954; Keller 1975; Ruiz and Vargas-Silva 2013; Bauer et al. 2013; Charnysh 2019; Bharadwaj and Mirza 2019). There is an opportunity here for scholars working on the ancient world to engage with this literature, even if the challenges of collecting the necessary data, for example on incomes and wealth over the course of several generations, may be insurmountable.

To his injunction to pursue other avenues, I would add that oral testimony of the kind already mentioned provides at least some scope for the voices of the displaced to emerge alongside the official record which is often bland and lofty in tone. In this respect, one can only endorse his remark about the agency wielded or reasserted by non-elite groups, including refugees who resisted outright or who might be able to deploy the weapons of the weak (Scott 1985). Whether, as Jewell implies (p. 31), vulnerable people demonstrated 'resilience' is, however, a moot point: this somewhat patronising term has become a buzzword among aid workers and others, and its conservative connotations need to be unpicked quite carefully (Evans and Reid 2014). Nevertheless, at the very least, scholars should be careful not to assume that refugees lacked the resources to exercise agency, whether they found themselves in refugee camps or in less confined settings.

Funding: This research received no external funding.

Conflicts of Interest: The author declares no conflict of interest.

\section{References}

Ahonen, Pertti. 2018. Europe and Refugees: 1938 and 2015-2016. Patterns of Prejudice 52: 135-48. [CrossRef]

Bauer, Thomas K., Sebastian Braun, and Michael Kvasnicka. 2013. The Economic Integration of Forced Migrants: Evidence for Postwar Germany. Economic Journal 123: 998-1024. [CrossRef]

Bauman, Zygmunt. 1989. Modernity and the Holocaust. Cambridge: Polity Press.

Bennett, Olivia, and Christopher McDowell. 2012. Displaced: The Human Cost of Development and Resettlement. New York: Palgrave Macmillan.

Bharadwaj, Prashant, and Rinchan Ali Mirza. 2019. Displacement and Development: Long Term Impacts of Population Transfer in India. Explorations in Economic History 73: 101273. [CrossRef]

Charnysh, Volha. 2019. Diversity, Institutions, and Economic Outcomes: Post-WWII Displacement in Poland. American Political Science Review 113: 423-41. [CrossRef]

Colson, Elizabeth. 1971. The Social Consequences of Resettlement. Manchester: Manchester University Press.

Colson, Elizabeth. 2003. Forced Migration and the Anthropological Response. Journal of Refugee Studies 16: 1-18. [CrossRef]

Evans, Brad, and Julian Reid. 2014. Resilient Life: The Art of Living Dangerously. Cambridge: Polity. 
Gatrell, Peter. 1999. A Whole Empire Walking: Refugees in Russia during World War 1. Bloomington: Indiana University Press.

Gatrell, Peter. 2013. The Making of the Modern Refugee. Oxford: Oxford University Press.

Ghosh, Alok Kumar Ghosh. 2000. Bengali Refugees at Dandakarayna: A Tragedy of Rehabilitation. In Refugees in West Bengal: Institutional Processes and Contested Identities. Edited by Pradip Kumar Bose. Calcutta: Calcutta Research Group, pp. 106-29.

Jewell, Evan. 2019. (Re)moving the Masses: Colonisation as Domestic Displacement in the Roman Republic. In Displacement and the Humanities: Manifestos from the Ancient to the Present. Edited by Elena Isayev and Evan Jewell. Special issue, Humanities 8: 66. Available online: https://www.mdpi.com/2076-0787/8/2/66 (accessed on 7 October 2019).

Keller, Stephen L. 1975. Uprooting and Social Change: The Role of Refugees in Development. Delhi: Manodar Books.

Malkki, Liisa H. 1996. Speechless Emissaries: Refugees, Humanitarianism, and Dehistoricization. Cultural Anthropology 11: 377-404. [CrossRef]

Rao, Vijendra Kasturi Ranga Varadaraja. 1954. An Economic Review of Refugee Rehabilitation in India: A Study of Nilokheri Township. Delhi: Delhi School of Economics.

Ribeiro, Beatriz, Fernando Oelze, and Orlando Soares Lopes. 2017. A Narrative of Resistance: A Brief History of the Dandara Community, Brazil. In Displacement and the Humanities: Manifestos from the Ancient to the Present. Edited by Elena Isayev and Evan Jewell. Special Issue, Humanities 6: 70. Available online: https://www.mdpi.com/2076-0787/6/3/70 (accessed on 7 October 2019).

Ruiz, Isabel, and Carlos Vargas-Silva. 2013. The Economics of Forced Migration. Journal of Development Studies 49: 772-84. [CrossRef]

Scott, James C. 1985. Weapons of the Weak: Everyday Forms of Peasant Resistance. New Haven: Yale University Press. Weiner, Amir, ed. 2003. Landscaping the Human Garden: Twentieth-Century Population Management in a Comparative Framework. Stanford: Stanford University Press.

(C) 2019 by the author. Licensee MDPI, Basel, Switzerland. This article is an open access article distributed under the terms and conditions of the Creative Commons Attribution (CC BY) license (http://creativecommons.org/licenses/by/4.0/). 